\title{
PENDIRIAN BANK SAMPAH PADA KELOMPOK IBU RUMAH TANGGA DI DESA JATITENGAH, KECAMATAN SUGIHWARAS, KABUPATEN BOJONEGORO
}

\author{
Shochrul Rohmatul Ajija ${ }^{1}$, Muryani ${ }^{2}$, Sylva Alif Rusmita ${ }^{3}$ \\ Universitas Airlangga, Surabaya, Indonesia ${ }^{1,2,3}$
}

\begin{abstract}
Jatitengah Village is one of the villages located in Sugihwaras District, Bojonegoro Regency. The main problem being faced by Jatinegara village is poverty and waste. The community is less able to manage waste properly. Much garbage is thrown in the garden or rice field. Seeing these conditions the establishment of a waste bank is very important to do, so that people are aware of a healthy and clean environment. In addition the community can increase income through waste management. There are 4 (four) outcomes of this program. Among them are 1) publications in ISSN journals; 2) publication in print / electronic mass media; 3) video of the activity; and 4) availability of adequate facilities and infrastructure of the waste bank and the operation of the waste bank properly.
\end{abstract}

Keywords:Garbage Bank; Housewife Group;Bojonegoro

\begin{abstract}
Abstrak
Desa Jatitengah merupakan salah satu desa yang terletak di Kecamatan Sugihwaras, Kabupaten Bojonegoro. Masalah utama yang sedang dihadapi desa Jatinegara adalah masalah kemiskian dan sampah. Masyarakat kurang dapat mengelola sampah dengan baik. Banyak sampah yang dibuang di kebun atau sawah. Melihat kondisi tersebut pendirian bank sampah sangatlah penting untuk dilakukan, agar masyarakat sadarakan lingkungan yang sehat dan bersih. Selainitumasyarakatdapatmenambahpenghasilanmelaluipengelolaansampah. Terdapat 4 (empat) luaran dari program ini. Diantaranya adalah 1) publikasi di jurnal ber ISSN; 2) publikasi di media massa cetak/elektronik; 3) video kegiatan; dan 4) tersedianya sarana dan prasarana bank sampah yang memadai serta berjalannya operasional bank sampah dengan baik.
\end{abstract}

Kata Kunci: Bank Sampah; Kelompok Ibu Rumah Tangga; Bojonegoro

\section{PENDAHULUAN}

Jumlah sampah terus bertambah seiring bertambahnya jumlah penduduk dan aktivitas masyarakat yang semakin beragam. Sampah merupakan sisa material dari suatu kegiatan, yang sudah tidak dibutuhkan lagi (Ariadi \& Tashid, 2019). Masalah sampah di Indonesia merupakan masalah yang belum sepenuhnya dapat teratasi. Hal ini dikarenakan jumlah sampah yang sangat banyak sedangkan kesadaran masyarakat tentang pentingnya menjaga lingkungan masih kurang (Purbaningrum, Utami, Wijayati, \& Wulandari, 2019). Permasalahan sampah yang tidak segera ditangani akan dapat merugikan lingkungan, apalagi dikawasan pemukiman masyarakat yang padat. Rumah tangga juga akan dapat memberikan pengaruh terhadap lingkungan, baik perkotaan atau desa terkait permasalahan sampah (Afriza, Roro, \& Nurdianti, 2018). Selain itu permasalahan sampah dapat menimbulkan penyakit serta pemukiman yang kumuh dan tidak layak huni (Listyaningrum, Hamdani, Aminuddin, Philona, \& Gerhan, 2019).

Salah satu wilayah yang memiliki permasalahan sampah yaitu Desa Jati tengah. Desa Jati tengah merupakan salah satu desa di Kecamatan Sugih waras Kabupaten Bojonegoro (Mujib, 2015). Masyarakat di desa ini masih mengolah sampah secara konvensional yaitu dengan membuang sampah tidak pada tempatnya dan membuang di kebun atau sawah. Keberadaan sampah di sekitar kita sekarang ini tidak dapat dihindari lagi. Minimnya kesadaran masyarakat untuk membuang sampah pada tempatnya menjadikan lingkungan disekitar terlihat kotor.

\footnotetext{
${ }^{1}$ Corresponding author: shochrul-r-a@feb.unair.ac.id
} 


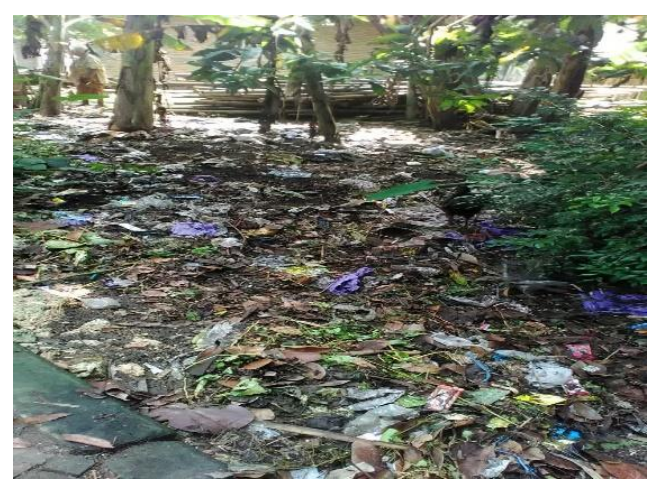

Gambar 1. Kondisi Sampah di Desa Jati tengah

Gambar tersebut adalah kondisi sampah yang berada di Desa Jati tengah Kecamatan Sugihwaras Kabupaten Bojonegoro. Terlihat sampah yang berserakan, kotor, dan menumpuk yang menyebabkan nilai estetika keindahan dan kebersihan lingkungan yang rendah. Membuang sampah sembarangan akan menghasilkan kondisi lingkungan yang kurang nyaman bagi masyarakat, bau yang tidak sedap dan masyarakat akan mudah terjangkit penyakit karena tidak sehatnya lingkungan tempat tinggal. Dalam mengatasi permasalahan sampah, maka perlu adanya pengelolaan dengan menggunakan prinsip mengurangi timbulnyasampah, menggunakan kembali sampah, dan mendaur ulang sampah (reduce, reuse dan recycle atau disingkat 3R) (Rahmi, 2019).

Selain permasalahan sampah, permasalahan lain yang dihadapi masyarakat desa Jati tengah adalah kemiskinan. Sumber pendapatan yang biasa diperoleh rumah tangga di pedesaan menurut Ellis (2000) adalah: a) Sektor on farm income, yaitu pendapatan yang diperoleh dari pertanian (2) Sektor off farm income, yaitu pendapatan yang masih dalam lingkup pertanian tapi tidak berhubungan langsung dengan sector pertanian misalnya sewalahan (3) Sektor non farm income, pendapatan yang berasal dari luar sector pertanian misalnya pendapatan dari usaha. Sedangkan masyarakat di desa Jati tengah sebagian besar bermata pencaharian sebagai petani. Fenomena kemiskinan di kalangan petani saat ini masih banyak ditemukan (Nuryati, Sulistyowati, Setiawan, \& Noor, 2019). Dari hasil pengamatan penulis, masyarakat desa Jati tengah yang keadaan ekonomi mampu biasanya memiliki lahan sawah yang luas, sehingga hasil panen melimpah. Sedangkan masyarakat dengan ekonomi menengah ke bawah rata-rata mempunyai sawah yang tidak cukup luas dan kebanyakan adalah buruh tani yang tidak memiliki lahan pertaian. Masyarakat yang melakukan aktivitas bertani atau ke sawah tidak hanya laki-laki saja (suami) akan tetapi juga perempuan (istri).

Dalamsegipendapatan para buruh tani, tenaga laki-laki biasanya di bayar Rp. 70.000 (tujuh puluh ribu rupiah) dalam sehari dan Rp. 30.000 (tiga puluh ribu rupiah) bagi tenaga perempuan. Hal ini dikarenakan pembagian pekerjaan yang relative berbeda dimana pekerjaan perempuan biasanya lebih ringan seperti menanam atau mencabut rumput. Namun demikian, kegiatan bertani tidaklah dilakukan setiap hari, terutama bagi buruh tani, tenaganya paling banyak dibutuhkan saat musim tanam tiba dan saat musim panen. Sisanya, yaitu saat masa perawatan tidak dibutuhkan banyak tenaga kerja, sehingga sebagian dari buruh tani mengganggur. Masyarakat yang hidup di daerah pedesaan dan dalam lingkungan pertanian tidak semua memiliki kemampuan bercocok tanam, atau menjadi buruh tani terutama bagi masyarakat perempuan. Mayoritas masyarakat perempuan berprofesi sebagai ibu rumah tangga. Sehingga,dibutuhkan adanya program pemberdayaan untuk membantu masyarakat terutama ibu rumah tangga agar memperoleh kesempatan dalam meningkatkan pendapatannya. Pemberdayaan adalah suatu proses untuk berdaya, memiliki kekuatan, kemampuan dan tenagauntuk menguasai sesuatu, pemberdayaan merupakan suatu usaha yang ditujukan untuk mensejahterakan masing-masing individu (Takalawangen, Mantiri, \& Monintja, 2019)

Melihat hal tersebut perlu adanya pendirian bank sampah di Desa Jati tengah sebagai upaya menanggulangi sampah sekaligus sebagai bentuk pemberdayaan masyarakat miskin terutama ibu rumah tangga. Bank sampah adalah suatu sarana yang digunakan untuk menghimpun sampah yang sudah dipilah oleh masyarakat. Hasil dari pengumpulan sampah yang sudah dipilah akan disetorkan ketempat pembuatan kerajinan dari sampah atau ketempat pengepul sampah. Bank sampah dikelola menggunakan system seperti perbankkan yang dilakukan oleh petugas sukarelawan. Penyetor adalah warga yang tinggal di sekitar lokasi bank serta mendapat buku tabungan seperti menabung di bank (Sasongko\& Putri, 2019).

Tujuan dibangunnya bank sampah bukan hanya untuk sampah itu sendiri tetapi juga sebagai strategi untuk membangun kepedulian masyarakat agar dapat "berkawan" dengan sampah dan mendapatkan 
manfaat financial langsung dari sampah. Sehingga manfaat yang dirasakan masyarakat tidak hanya ekonomi kerakyatan yang kuat, namun pembangunan lingkungan yang bersih dan hijau guna menciptakan lingkungan masyarakat yang sehat dan nyaman.

\section{MATERI DAN METODE PELAKSANAAN} alurberikut:

Terdapattujuhtahapanpelaksanaan program pengabdianmasyarakatini. Hal initampak pada diagram

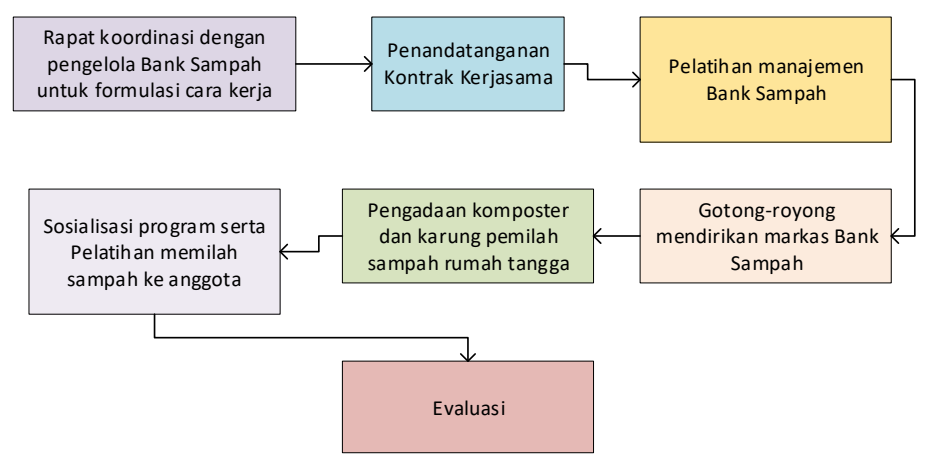

Gambar 2. Tahapan Pelaksanaan Kegiatan

Secara garis besar, perbaikan sistem pengelolaan sampah akan ditempuh melalui tiga pendekatan. Diantaranya adalah sebagai berikut:

1. Reduce (mengurangi sumber sampah): penghematan penggunaan sumber daya alam dan pembatasan konsumsi penggunaan bahan dalam kegiatan sehari-hari.

2. Reuse: penggunaan produk yang dikonsumsi berulang-ulang.

3. Recycle: pendaur-ulangan bahan yang tidak dapat digunakan langsung, mengolah menjadi kompos

Penyelenggaraan pengelolaan sampah merupakan sebuah pelayanan public dimana pemerintah bertanggungjawab dalam penyediaan sarana dan prasarana pengelolaan sampah yang melibatkan pihak ketiga dan partisipasi masyarakat. Perbaikan tata kelola sampah ini diharapkan dapat mengatasi masalahmasalah yang ditimbulkan oleh sampah terhadap lingkungan hidup dan kesehatan masyarakat.

Undang-undang Republik Indonesia Nomor 18 Tahun 2008 Tentang Pengelolaan Sampah dalam Pasal 22 ayat (1) menjelaskan tentang kegiatan penanganan sampah meliputi:

a. Pemilahan dalam bentuk pengelompokan dan pemisahan sampah sesuai dengan jenis, jumlah, dan sifat sampah.

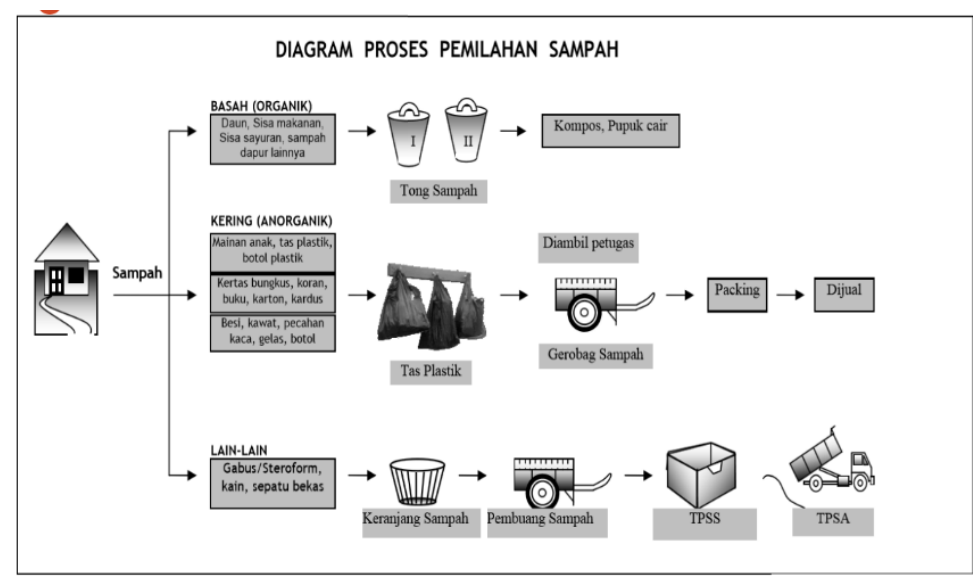

Gambar 3. Proses Pemilahan Sampah Rumah Tangga (SNI 3242:2008 - Pengelolaan sampah di permukiman)

b. Pengumpulan dalam bentuk pengambilan dan pemindahan sampah dari sumber sampah ke tempat penampungan sementara atau tempat pengolahan sampah terpadu. Pola pengumpulan sampah pada dasarnya dikempokkan dalam 2 (dua) yaitu pola individual dan pola komunal (SNI 19-2454-2002). Pola individu artinya proses pengumpulan sampah dimulai dari sumber sampah 
kemudian diangkut ke tempat pembuangan sementara / TPS sebelum dibuang ke TPA. Sedangkan untuk pola komunal artinya Pengumpulan sampah dilakukan oleh penghasil sampah ke tempat penampungan sampah komunal yang telah disediakan / ke truk sampah yang menangani titik pengumpulan kemudian diangkut ke TPA tanpa proses pemindahan. Sistem pengumpulan sampah di Kelurahan Tanah Kali Ke dinding dapat digambarkan sebagai berikut :

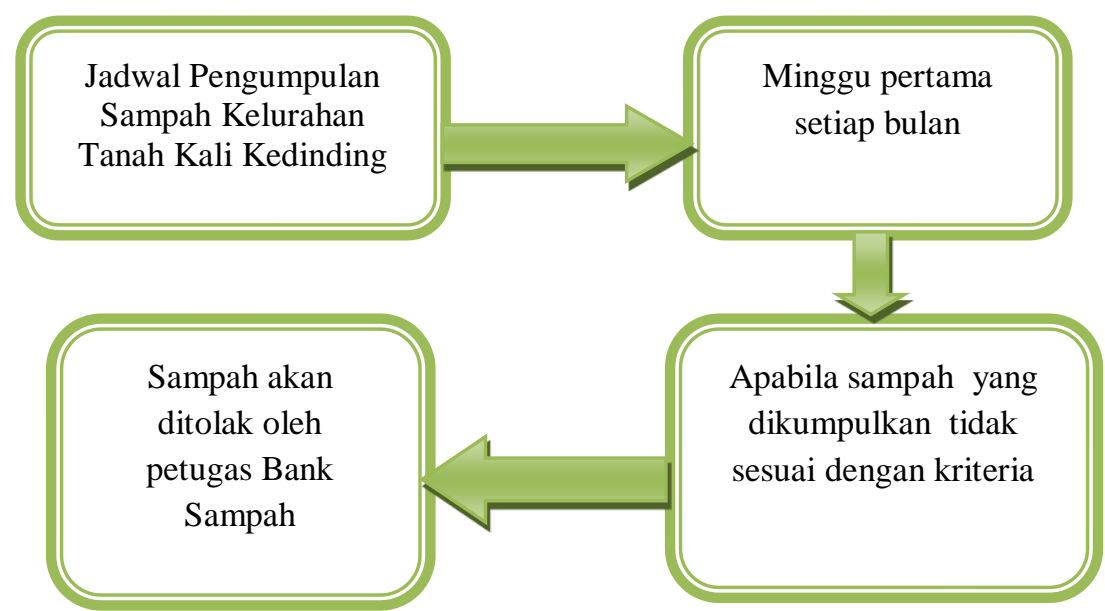

Gambar 4. Sistem pengumpulan sampah di kelurahan Tanah kali ke dinding

c. Pengangkutan dalam bentuk membawa sampah dari sumber atau dari tempat penampungan sampah sementara atau dari tempat pengolahan sampah terpadu menuju ke tempat pemrosesan akhir.

d. Pengolahan dalam bentuk mengubah karakteristik, komposisi, dan jumlah sampah. Dalam mengelola sampah, masyarakat dapat memanfaatkannya menjadi sebuah kerajinan, seperti kerajinan yang terbuat dari sampah plastik yang dapat dibuat menjadi barang-barang bernilai ekonomis, seperti tas, bros, dan lain-lain.

e. Pemrosesan akhir sampah dalam bentuk pengembalian sampah atau residu hasil pengolahan sebelumnya ke media lingkungan secaraaman.

Selain memperbaiki system pengelolaan sampah, terdapat salah satu aspek penting dalam pengelolaan sampah, yaitu aspek pembiayaan yang berfungsi untuk membiayai operasional pengelolaan sampah yang dimulai dari sumber sampah/penyapuan, pengumpulan, transfer dan pengangkutan, pengolahan dan pembuangan akhir. Dalam menunjang keberhasilan pengelolaan sampah, perlu adanya reward kepada karyawan-karyawan Bank Sampah sebagai bentuk apresiasi yang telah membantu dalam pengelolaan sampah.

\section{HASIL DAN PEMBAHASAN}

Hasil yang dicapai pada pertemuan pertama pelatihan pendirian bank sampah di Desa Jati tengah adalah terlaksananya sosialisasi awal dari Ibu Siti Muchaiyah yang berhasil mendirikan bank sampah di Mojokerto. Selain itu, kelompok ibu rumah tangga Desa Jati tengah diberikan pelatihan pengelolaan sampah plastic untuk dijadikan sebuah karya yang bernilai jual. Kegiatan ini dihadiri oleh 20 ibu rumah tangga yang rata-rata berusia 30 tahun keatas dan banyak bekerja di sector pertanian. Pendapatan setiap bulannya rata-rata Rp. 2.000 .000 yang terkadang belum cukup untuk memenuhi kebutuhan. Disisi lain, kelompok ibu rumah tangga tersebut jarang sekali memilah sampah rumah tangga serta belum bias mengolah sampah-sampah tertentu yang sebenarnyadapatdijadikan sebagai sumber pendapatan. Oleh karena itu, pelatihan bertujuan untuk menanamkan rasa peduli akan lingkungan sekitar serta pemanfaatan sampah menjadi sumber penghasilan tambahan kelompok ibu rumah tangga Desa Jati tengah.

Kegiatan pelatihan pendirian Bank Sampah Kelompok Ibu Rumah Tangga Desa Jati tengah dilaksanakan pada hari minggu, 30 Juni 2019 pukul 08:30 hingga 15:00. Sosialisasi awal merupakan tahapan pertama yang dilakukan untuk mendirikan bank sampah di Desa Jati tengah. Sosialisasi ini bertujuan untuk memberikan pengenalan dan pengetahuan dasar mengenai bank sampah. Dalam sosialisasi ini, peserta kegiatan kelompok ibu rumah tangga diberikan pemahaman secara gambling tentang manfaat bank sampah, alur pengelolaan sampah pada sistem bank sampah, serta teknis bagi hasil pengelolaan sampah. Selanjutnya, pada tahapan ini kelompok ibu rumah tangga diberikan pengenalan mengenai jenis- 
jenis sampah, proses dalam memilah sampah, nilai ekonomis sampah, serta bahaya sampah-sampah di lingkungan sekitar yang tidak dikelola dengan baik.Berikut ini tabel mengenai susunan kegiatan visitasi pertama:

Tabel 1. Susunan Kegiatan Visitasi Pertama

\begin{tabular}{|c|c|}
\hline Waktu & Kegiatan \\
\hline 08:30 - 09:00 & RegistrasiPeserta \\
\hline 09:00 - 09:15 & Pembukaan dan sambutandari Bu Shochrul \\
\hline 09:15 - 09:30 & SambutandariIbuLurah \\
\hline 09:30 - 10:30 & PenyuluhanManajemen Bank Sampah oleh Bu Shochrul \\
\hline $10: 30-12: 00$ & PelatihanMembuatKerajinanTangan Tas dariGelasBekasTeh Rio \\
\hline 12:00 - 13:00 & Ishoma \\
\hline $13: 00-14: 30$ & $\begin{array}{l}\text { PelatihanMembuatKerajinanTangan Tas dariGelasBekasTeh Rio } \\
\text { (Lanjutan) }\end{array}$ \\
\hline 14:30 - 15:00 & Penutupan \\
\hline
\end{tabular}

Kegiatan selanjutnyaadalah pelatihan dalam mengolah sampah plastik khususnya gelas bekas teh rio yang diubah menjadi kerajinan cantik berupa tas keranjang. Pertama, ibu Sri Utami sebagai pelatih kerajinan menjelaskan tentang bahan-bahan yang digunakan serta langkah-langkah pembuatan. Langkahlangkah tersebut meliputi persiapan bahan yang digunakan: gelang-gelang bekas teh rio yang telah dicuci bersih, benang kur, korek api, cutter, dll. Kedua, gelang-gelang tersebut dirangkai menggunakan benang kur hingga terbentuk rangkaian memanjang. Ketiga, setelah menjadi rangkaian yang Panjang,ikatkansampaimenjaditigabagian, setiapbagianberisi 38 gelang atau dapatdisesuaikan dengan kemauan sendiri hingga membentuk kerangka. Lakukan dengan pola yang sama hingga membentuk tas keranjang yang cantik. Terakhir, peserta bebas berkreasi untuk membentuk tas yang di inginkan, seperti menambahkan hiasan-hiasan bunga agar tas tersebut terlihat menarik.

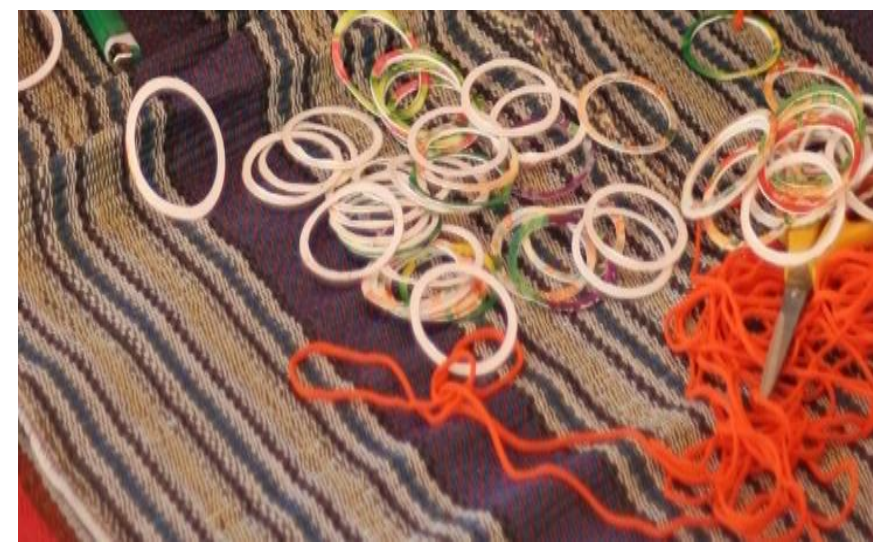

Gambar 3.Bahan Pembuatan Tas Daur Ulang

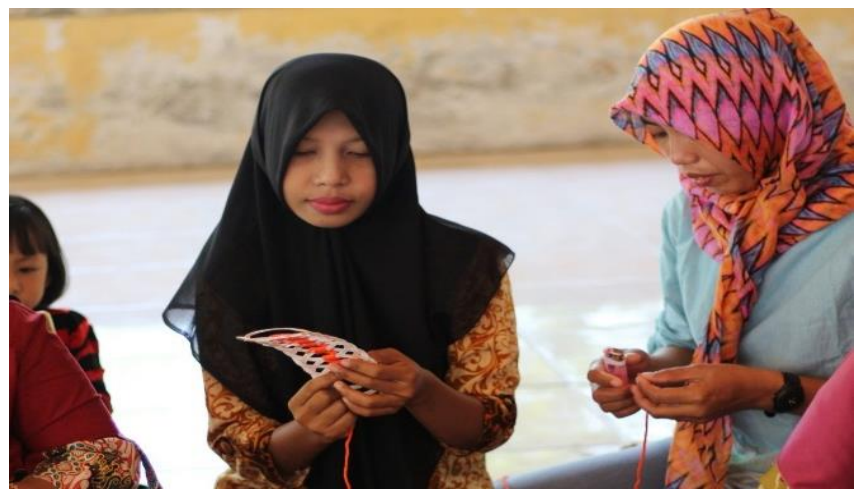

Gambar 4. Proses Merajut Sampah Gelas Plastik 


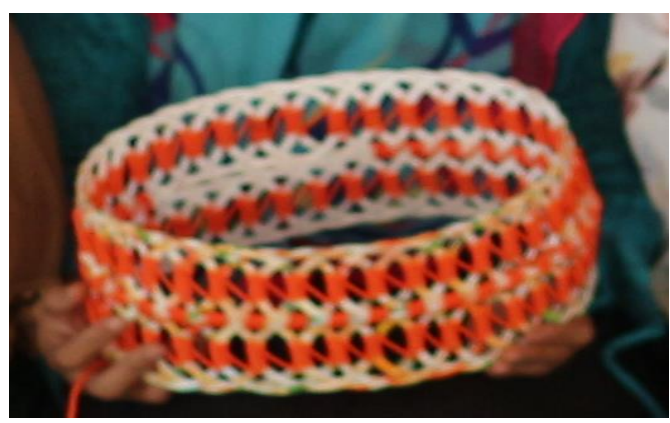

Gambar 5. Kerangka Tas

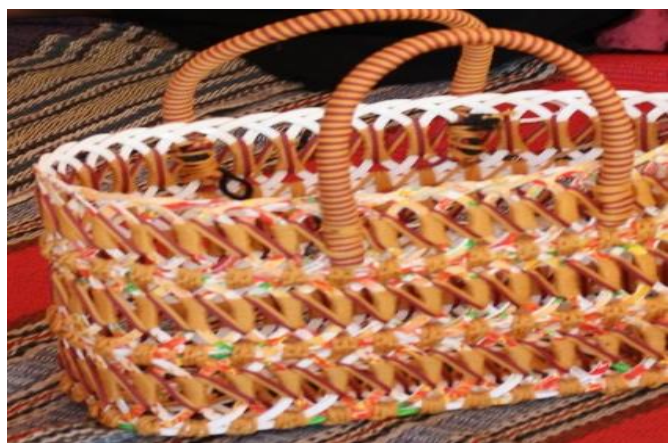

Gambar 5. Tas SebelumFinishing

Visitasi kedua dilaksanakan pada hari minggu, 18 Agustus 2019. Visitasi kedua memiliki dua agenda, yakni pendampingan pelatihan pengolahan sampah serta pelatihan pemasaran hasil daur ulang sampah. Pelatihan pengolahan sampah tidak jauh berbeda dengan pelatihan pada visitasi pertama, akan tetapi teknik pembuatannya sedikit lebih rumit. Lebih lanjut, setelah mengikuti pelatihan pengolahan sampah, peserta melakukan sharing untuk mengolah bonggol pisang (batang pisang bagian umbi batang) menjadi produk makanan ringan berupa kripik Ares. Produk-produk tersebut tergolong produk baru yang belum diketahui masayarakat. Pendampingan pemasaran yang intensif diperlukan karena ibu-ibu rumah tangga Desa Jatitengah belum menguasai cara-cara pemasaran produk-produk yang telah dihasilkan, termasuk promosi, distribusi produk, dan sebagainya. Oleh karena itu, untuk menjaga keberlanjutan program dilakukan monitoring dan evaluasi. Pendampingan pemasaran intensif dilaksanakan melalui peningkatan penerapan iptek di masyarakat (mekanisasi, IT, dan manajemen) berupa penyediaan sarana prasarana yang memadai serta berjalannya operasional bank sampah dengan baik. Modul pendirian bank sampah serta pengelolaan limbah organik serta nonorganik sebagai referensi dan acuan masyarakat dalam pengembangan bank sampah.

\section{KESIMPULAN DAN SARAN}

\section{Kesimpulan}

Secara keseluruhan kegiatan pengabdian masyarakat di Desa Jatitengah telah berjalan dengan lancar dan mendapat tanggapan positif dari peserta. Seluruh peserta mengikuti program tersebut dari pertemuan pertama hingga pertemuan terakhir. Kegiatan pengabdian masyarakat ini berhasil menumbuhkan kesadaran dan kepedulian masyarakat akan pengelolaan sampah serta memberikan ketrampilan dalam mengolah atau mendaur ulang sampah secara mandiri. Pelatihan pengolahan sampah menjadi barang bernilai jual diisi dengan pelatihan sampah anorganik berupa teh kemasan gelas diubah menjadi tas keranjang, serta sampah organik bonggol pisang yang diolah menjadi keripik Ares. Selain itu, pendampingan pemasaran yang intensif juga dilakukan melalui penerapan iptek di masyarakat serta penyediaan modul pendirian bank sampah serta pengelolaan limbah organik dan nonorganik sebagai referensi dan acuan masyarakat untuk pengembangan bank sampah. untuk menjaga keberlanjutan.

\section{Saran}

Diperlukan kegiatan lebih lanjut untuk meningkatkan pencapaian pendirian bank sampah di Desa Jatitengah serta monitoring dan evaluasi dalam hal pengelolaan sampah. Kegiatan lain yang dapat mendorong industri kreatif berbasis sampah perlu ditingkatkan sehingga kegiatan ini tidak hanya menumbuhkan kreativitas masyarakat, namun dapat bermanfaat sebagai tambahan pendapatan dalam 
rangka pemberdayaan masyarakat. Selanjutnya, perlu adanya kerjasama dengan dinas terkait dalam hal pengelolaan sampah di Desa Jatitengah.

\section{REFERENSI}

Afriza, E. F., Roro, R., \& Nurdianti, S. (2018). Edukasi Ecobrik Sebagai Solusi Manajemen Pengelolaan Sampah Berbasis Masyarakat, 2, 799-807.

Ariadi, D., \& Tashid, T. (2019). Prototipe Sistem Pengukur Ketinggian Permukaan Sampah Pada Tempat Pembuangan Sementara Menggunakan Arduino Dan Web Gis. JOISIE (Journal Of Information Systems And Informatics Engineering), 2(1), 18-25.

Ellis, F. (2000). The determinants of rural livelihood diversification in developing countries. Journal of Agricultural Economics, 51(2), 289-302.

Kamal, M., Waluyo, S., \& Kustiani, I. (2017). Pemberdayaan Civitas Akademika Dalam Pengelolaan Sampah Terpadu Universitas Lampung dan Pemanfaatan Mini Pembangkit Listrik Tenaga Biomassa.

Listyaningrum, N., Hamdani, A. R., Aminuddin, A., Philona, R., \& Gerhan, A. (2019). Refleksi Pengelolaan Sampah terhadap Kesehatan Di Kabupaten Lombok Barat Ntb. Media Keadilan-Jurnal Ilmu Hukum, 9(2), 159-171.

Mahyudin, R. P. (2017). Kajian Permasalahan Pengelolaan Sampah dan Dampak Lingkungan di TPA. Jurnal Teknik Lingkungan, 66-74.

Mujib, M. (2015). Pemberdayaan Petani Jamur Tiram: Studi Perubahan Pola Pikir Masyarakat Tentang Budidaya Jamur Tiram Desa Pancur Kec. Temayang Kab. Bojonegoro. UIN Sunan Ampel Surabaya.

Muryani, Ajija, S. R., \& Rachmayanti, R. D. (2018). Peran Penting Bank Sampah Untuk Peningkatan Pendapatan Masyarakat. Surabaya.

Nuryati, R., Sulistyowati, L., Setiawan, I., \& Noor, T. I. (2019). Kesejahteraan Petani Pelaku Usahatani Polikultur Terintegrasi di Kabupaten Tasikmalaya. Mimbar Agribisnis: Jurnal Pemikiran Masyarakat Ilmiah Berwawasan Agribisnis, 5(2), 206-223.

Pratama, J. N. (2018, April). Tata Kelola Sampah di Kota Pekan Baru (Studi Kasus Pada Bank Sampah di Kota Pekan Baru Tahun 2016). 5.

Purbaningrum, A. D., Utami, R., Wijayati, R., \& Wulandari, Y. (2019). Pengolahan Kembali Sampah Plastik Menjadi Kerajinan Cantik Sebagai Upaya Pengurangan Pencemaran Lingkungan. INA-Rxiv. July, 10.

Rahmi, M. (2019). Pengorganisasian Masyarakat Melalui Bank Sampah "Gema Bersatu" di Gampong Ateuk Pahlawan Kecamatan Baiturrahman Banda Aceh. Jurnal Samudra Ekonomika, 3(1), $19-25$.

Sasongko, N., \& Putri, E. (2019). Pengabdian Masyrakat tentang Penitngnya Penyusunan Laporan Keuangan pada Bank Sampah. Prosiding Seminar Bisnis Magister Manajemen (SAMBIS) 2019.

Suyanto, E., Soetarto, E., Sumardjo, \& Hardjomidjojo, H. (2015). Model Kebijakan Pengelolaan Sampah Berbasis Partisipasi "Green Community" Mendukung Kota Hijau. 143-152.

Takalawangen, M., Mantiri, M., \& Monintja, D. (2019). Peran Pemerintah Dalam Pemberdayaan Pemuda di Desa (Lesabe Tabukan Selatan Kabupaten Kepulauan Sangihe). Jurnal Eksekutif, 3(3).

Wulandari, R., \& Widodo, A. S. (2016). IbM Pemberdayaan Asisten Rumah Tangga Dalam Pengelolaan Sampah Rumah Tangga 